\title{
Fourth Derivative Spectrophotometric Method for the Determination of Fungicide Maneb Using Sodium Molybdate
}

\author{
Manpreet Kaur, Ashok Kumar Malik, Baldev Singh \\ Department of Chemistry, Punjabi University, Patiala, India \\ E-mail: malikchem2002@yahoo.co.uk \\ Received November 26, 2010; revised December 29, 2010; accepted March 1, 2011
}

\begin{abstract}
A highly sensitive fourth derivative spectrophotometric method is presented for the residue analysis of ethylenebis dithiocarbamate fungicide Maneb. The fungicide maneb forms a blue complex with sodium molybdate on heating which is studied spectrophotometrically. The method has been successfully applied to maneb determination in wheat grains and soft drinks with high recoveries. The analytical sensitivity of the present method has been found to be $0.0011 \mu \mathrm{g} / \mathrm{mL}$.
\end{abstract}

Keywords: Derivative Spectrophotometry, Maneb, Sodium Molybdate

\section{Introduction}

Maneb (manganese ethylenebisdithiocarbamate) (Figure 1) is a common dithiocarbamate (DTC) fungicide available as dust and dispersible powder [1]. Maneb is active against a wide range of bacterial and fungal species, so, it is widely used on vegetable crops, in fields, orchards and vines, greenhouses, forestry and also for seed treatment [2]. Maneb is not systemic but rather a protective fungicide. Hence, its residues can be found on the fodder, fruit and other crops where it is sprayed. Ethylenebisdi-thiocarbamate (EBDC) fungicides like maneb have low human toxicity but their degradation to Ethylene thiourea (ETU) is of great toxicological concern [3-5] as it is associated with carcinogenic and teratogenic properties [6]. DTC complexes are toxic and have mutational effect [7]. Rathore et al. [8] have studied the mobility of DTC pesticides through soil and this aspect of their behavior presents severe hazards for the mankind as they can be washed in to drinking water sources thus entering our food chain. In the wake of above knowledge, it is imperative that highly sensitive and efficient methods be developed for the residue analysis of dithiocarbamate pesticides like maneb in various food and environmental samples. Most of the developed methods like spectrophotometry and gas chromatography [9] are based on the analysis of $\mathrm{CS}_{2}, \mathrm{H}_{2} \mathrm{~S}$ or amines, which are evolved during decomposition of EBDCs.
One of the earliest colorimetric methods for Maneb determination was developed by Hylin et al. [10] Türker et al. devised a flame atomic absorption spectrometry method for indirect determination of dithiocarbamate fungicides [11]. Crnogorac and Schwack have provided insight into the various methods for the residue analysis of dithiocarbamate fungicides [12]. Waseem et al. have used a flow-injection method for the analysis of DTC fungicides with chemiluminescence detection [13]. A microwave assisted extraction method involving hydrolysis of dithiocarbamates and their analysis in tobacco leaves was developed by Vryzas et al. [14] A DPP (Differential pulse polarographic) technique has been employed for the determination of DTC residues by Schwack et al. [15] Lo et al. have determined propineb, zineb, maneb and mancozeb by an HPLC method [16]. Česnik et al. have developed validation for a GC-MS

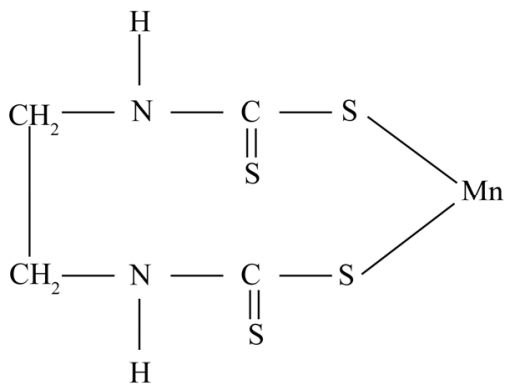

Figure 1. Structure of maneb. 
method for the determination of DTCs in foodstuffs [17]. Cronogorac et al. have presented a method using hydrophilic interaction-LC-Tandem Mass Spectrometry for the determination for DTC fungicide residues in fruit and vegetables [18]. Dithiocarbamates (DTCs) can also be determined by methods, like iodometry [19,20], indirect complexometry [21] and FTIR spectrometry [22]. But the methods discussed above have various disadvantages like:

1) Most of the methods except for the gas chromatography are indirect, time consuming and less sensitive.

2) The Gas chromatographic methods are sensitive but not selective as all the dithiocarbamate pesticides evolve carbon disulphide on acid hydrolysis.

3) HPLC methods are out of bounds for several researchers as these are expensive and use toxic and expensive solvents.

In the present work, a relatively fast, simple, sensitive and selective derivative spectrophotometric method is presented for the analysis of Maneb by converting it into molybdenum complex. Maneb reacts with sodium molybdate on heating to form a blue coloured complex. Maneb and sodium molybdate combine in the ratio 1:2 to form complex. Maneb releases $\mathrm{Mn}^{2+}$ and dithiocar- bamate unit, the latter forms complex with sodium molybdate, which is then extracted into methyl isobutyl ketone (MIBK) and determined by derivative spectrophotometry. The significant advantage of this method over the gas chromatographic methods is that it can be applied for the direct determination of Maneb in the presence of other dithiocarbamates like Ziram, Nabam and Zineb.

\section{Materials and Methods}

\subsection{Equipment and Reagents}

Elico SL-164, Double Beam UV-Vis spectrophotometer was used. Maneb standard was obtained from Riedel de Haën, Germany. A stock solution was prepared by heating $100 \mathrm{mg}$ of Maneb in $100 \mathrm{~mL}$ of $0.1 \mathrm{~mol} \cdot \mathrm{L}^{-1}$ of $\mathrm{NaOH}$. Further dilutions were carried out with $0.1 \mathrm{~mol} \cdot \mathrm{L}^{-1}$ of $\mathrm{NaOH}$ as required. A $2 \%(\mathrm{~m} / \mathrm{v})$ solution of sodium molybdate was prepared in doubly distilled water.

\subsection{Procedures}

\subsubsection{Absorption Spectra}

$2 \mathrm{~mL}$ of $2 \%$ sodium molybdate solution and $1 \mathrm{~mL}$ of $2 \mathrm{~mol} \cdot \mathrm{L}^{-1}$ of $\mathrm{H}_{2} \mathrm{SO}_{4}$ were added to an aliquot containing $100 \mu \mathrm{g}$ of Maneb. The mixture was boiled for 5 minutes, cooled and water was added to make the volume $5 \mathrm{~mL}$. The blue complex formed was extracted into $5 \mathrm{~mL}$ of MIBK (methyl isobutyl ketone) with shaking. The or- ganic layer was collected into a test tube containing fused $\mathrm{CaCl}_{2}$ to remove any moisture. The solution was then decanted into a $1 \mathrm{~cm}$ cell and the spectra were taken against a reagent blank. The molybdenum complex shows peaks at $670 \mathrm{~nm}$ and $956 \mathrm{~nm}$ (Figure 2), but the peak at $956 \mathrm{~nm}$ has much higher absorbance; hence all the measurements were made at this wavelength. The first derivative, second derivative, third derivative and fourth derivative curves were given in Figures 3-6 respectively.

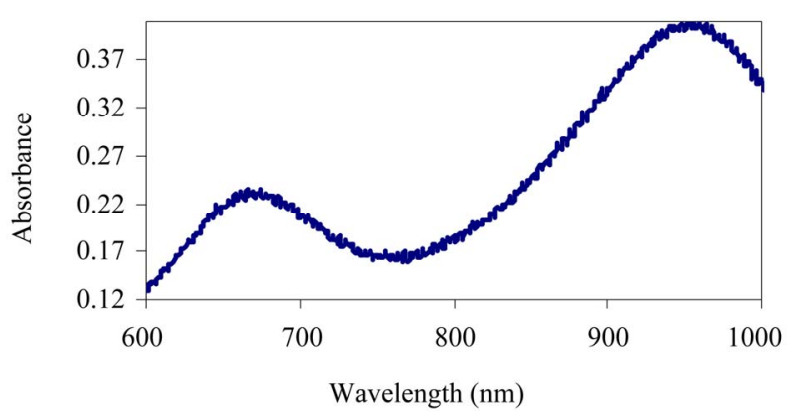

Figure 2. Zero order absorption spectra of Maneb-molybdate complex.

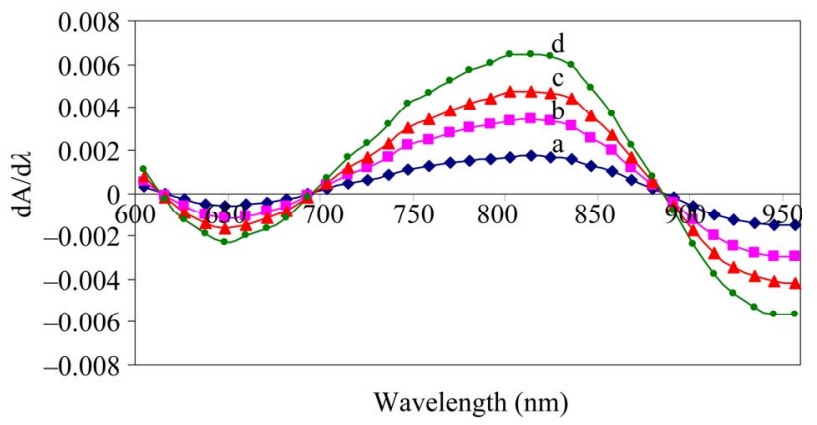

Figure 3. $1^{\text {st }}$ derivative curves of molybdenum-ethylenebisdithiocarbamate complex: $a, b$, c, d representing the amounts of Maneb in final solutions (a: 10, b: 20, c: 30 and d: $\left.40 \mu \mathrm{g} \cdot \mathrm{mL}^{-1}\right)$.

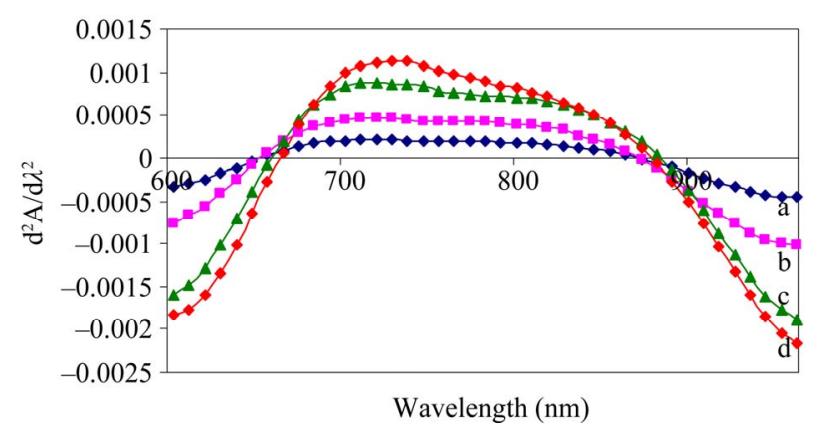

Figure 4. $2^{\text {nd }}$ derivative curves of molybdenum-ethylenebisdithiocarbamate complex: $a, b$, c, d representing the amounts of Maneb in final solutions (a: 10, b: 20, c: 30 and d: $\left.40 \mu \mathrm{g} \cdot \mathrm{mL}^{-1}\right)$. 


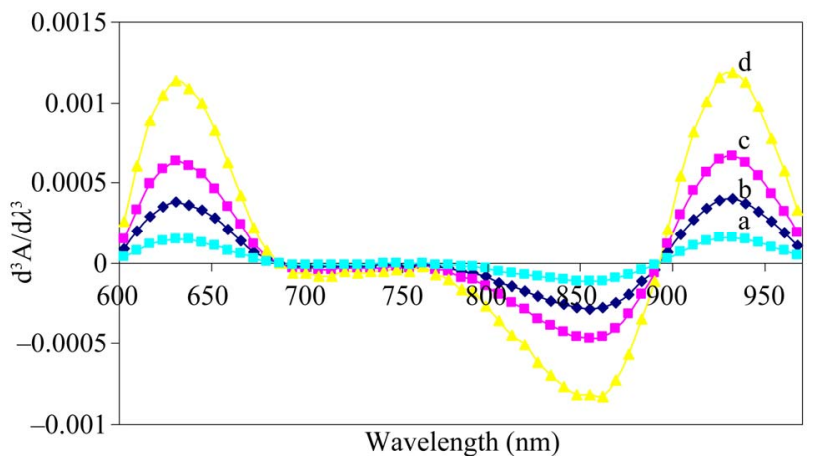

Figure 5. $3^{\text {rd }}$ derivative curves of molybdenum-ethylenebisdithiocarbamate complex: a, b, c, d representing the amounts of Maneb in final solutions (a: 10, b: 20, c: 30 and d: $40 \mu \mathrm{g} \cdot \mathrm{mL}^{-1}$ ).

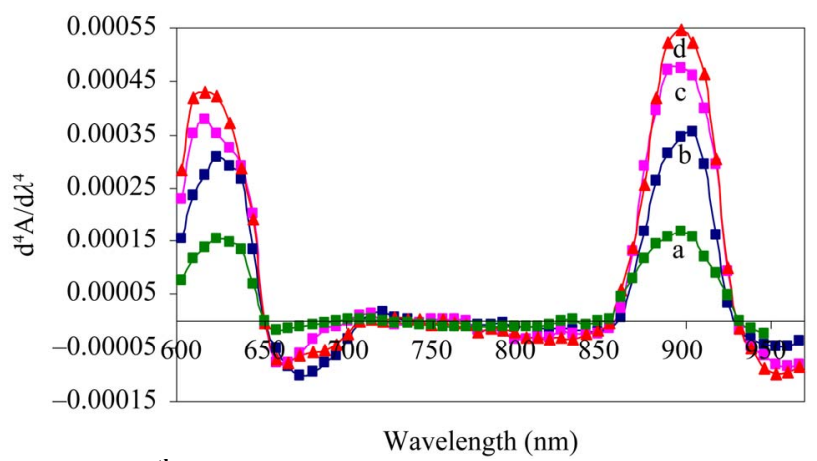

Figure 6. $4^{\text {th }}$ derivative curves of molybdenum-ethylenebisdithiocarbamate complex: a, b, c, d representing the amounts of Maneb in final solutions (a: 10, b: 20, c: 30 and d: $40 \mu \mathrm{g} \cdot \mathrm{mL}^{-1}$ ).

In DS (Derivative Spectrophotometry), the $\lambda$ reproducibility and $\mathrm{S}$ to $\mathrm{N}$ ratio are quite important. The features like peak height and noise level depend on parameters chosen like order of derivative; scan speed and integration time during recording of spectra. The use of optimum parameters will give better resolution and more sensitivity. For the $4^{\text {th }}$ derivative spectra, $\Delta \lambda=9 \mathrm{~nm}$ was found to be ideal.

\subsubsection{Preparation of Calibration Curve}

The known volumes of sample solutions having 10 - $250 \mu \mathrm{g}$ of Maneb were analysed by general procedure and the derivative spectra were obtained against a reagent blank prepared under the similar conditions. The characteristics of zero order spectrum are summarized in Table 1. The
Figures 3-6 show the derivative spectrum of different orders. The comparison of calibration curves of different derivative spectra are provided in the Table 2 .

\section{Results and Discussion}

\subsection{Beer's Law and Sensitivity}

The optimum wavelength interval was found to be $9 \mathrm{~nm}$ for high resolution and sensitivity. The wavelength range to obtain spectra was selected from $600 \mathrm{~nm}$ to $1100 \mathrm{~nm}$. The calibration curve was obtained by measuring the peak height between wavelength of 850 and $938 \mathrm{~nm}$. Absorbance of sodium molybdate complex with Maneb recorded against a reagent blank was linear over the concentration range from $2 \mu \mathrm{g} / 5 \mathrm{~mL}^{-1}$ to $40 \mu \mathrm{g} / 5 \mathrm{~mL}^{-1}$ of the final solution. The detection limit is $0.0011 \mu \mathrm{g} \cdot \mathrm{mL}^{-1}$ for Maneb when $\mathrm{S} / \mathrm{N}$ ratio was 3 .

\subsection{Effect of Heating Time}

It was observed that the absorbance of the complex increased up to a certain extent on increasing the heating time. Therefore, the reaction mixture was heated for different intervals of time. It was observed that an optimum heating time of 5 minutes was sufficient to obtain maximum absorbance. Increasing the heating time beyond this did not increase the absorbance as the complete complexation was achieved by heating for 5 minutes.

\subsection{Effect of Acid Concentration}

Maximum absorbance was observed when volume of acid added was between $1 \mathrm{~mL}$ to $1.5 \mathrm{~mL}$. A decrease in absorbance was observed on further increasing the amount of acid added as higher acid concentration is not conducive for complex formation.

Table 1. Different parameters of zero order spectrum.

\begin{tabular}{clc}
\hline $\begin{array}{c}\text { Serial } \\
\text { No. }\end{array}$ & \multicolumn{1}{c}{ Parameter } & $\begin{array}{c}\text { Zero order spectrum of } \\
\text { maneb-sodium } \\
\text { molybdate complex }\end{array}$ \\
\hline 1. & Molar Absorptivity $\left(\mathrm{L} \cdot \mathrm{mol}^{-1} \cdot \mathrm{cm}^{-1}\right)$ & $8.16 \times 10^{4}$ \\
2. & Sandell's Sensitivity $\left(\mu \mathrm{g} \cdot \mathrm{mL}^{-1}\right)$ & 0.0049 \\
3. & Analytical Sensitivity $\left(\mu \mathrm{g} \cdot \mathrm{mL}^{-1}\right)$ & 0.0011 \\
4. & Linear Range $\left(\mu \mathrm{g} \cdot \mathrm{mL}^{-1}\right)$ & 2 to 40 \\
\hline
\end{tabular}

Table 2. Comparison of calibration curves of Maneb using different derivative spectra.

\begin{tabular}{ccccccc}
\hline Zineb Complex & Order of Derivative & $\lambda(\mathrm{nm})$ & Regression Equation & $\mathrm{R}^{2}$ & S.D. of Slope & Analytical Sensitivity $\mu$ g.mL \\
\hline 1. & $1^{\text {st }}$ & 814 & $y=4 \times 10^{-5} x-0.0001$ & 0.9997 & $1.2 \times 10^{-6}$ \\
2. & $2^{\text {nd }}$ & 950 & $y=7 \times 10^{-6} x-0.0002$ & 0.9992 & $2.4 \times 10^{-7}$ \\
3. & $3^{\text {rd }}$ & 932 & $y=3 \times 10^{-6} x-5 \times 10^{-5}$ & 0.9995 & $1.4 \times 10^{-8}$ & 0.9 \\
4. & $4^{\text {th }}$ & 904 & $y=8 \times 10^{-7} x+7 \times 10^{-6}$ & 0.9994 & $2.3 \times 10^{-9}$ \\
\hline
\end{tabular}




\subsection{Effect of Other Ions}

Sample solutions containing $5 \mu \mathrm{g} \cdot \mathrm{mL}^{-1}$ of Maneb and various amounts of different alkali metal salts or metal ions were prepared and the general procedure was applied. It was observed that $20 \mathrm{mg}$ of following foreign anions didn't interfere in the determination of Maneb: bromide $(11 \mathrm{mg})$, acetate $(15 \mathrm{mg})$, chloride $(3.5 \mathrm{mg})$, fluoride $(2 \mathrm{mg})$, citrate $(20 \mathrm{mg})$ and EDTA $(0.06 \mathrm{mg})$. Of the metal ions examined, Mn(II) $(0.066 \mathrm{mg}), \mathrm{Mo}(\mathrm{IV})$ $(0.14 \mathrm{mg}), \mathrm{Ni}(\mathrm{II})(0.30 \mathrm{mg}), \mathrm{Co}(\mathrm{II})(0.009 \mathrm{mg}) \mathrm{did}$ not interfere. $\mathrm{Fe}(\mathrm{II})$ and $\mathrm{Zn}$ (II) were masked with $1 \mathrm{~mL}$ of $5 \% \mathrm{NaF}$ solution and $1 \mathrm{~mL}$ of $5 \% \mathrm{KCN}$ solution respecttively. $1 \mathrm{~mL}$ of $5 \%$ potassium iodide and thiourea were used to mask $\mathrm{Hg}$ (II) and $\mathrm{Cu}(\mathrm{II})$ respectively. It is thus clear that several ions like $\mathrm{Fe}, \mathrm{Zn}, \mathrm{Hg}$ etc. interfered in maneb determination

\subsection{Effect of Standing Time}

It was observed that the absorbance of the solution became constant after $2-3 \mathrm{~min}$. so after extracting into MIBK a 5 min. standing time was selected. The absorbance of the complex remained practically constant for about 30 minutes with the R.S.D. of absorbance values varying between $0.69 \%$ to $1.6 \%$ for different concentrations.

\section{Applications}

\subsection{Determination of Maneb from Fortified Samples of Wheat Grains and Soft Drinks}

The method was applied to the determination of Maneb from fortified samples of wheat grains, cabbage and soft drink samples.

\subsubsection{Sample Preparation for Food Stuffs}

20 grams of the foodstuff was finely crushed and solu- tion containing a known amount of maneb was added, it was mechanically shaken with $100 \mathrm{~mL}$ of ACN (Acetonitrile) for 1 hour. This mixture was filtered and the residue in funnel was washed with $3 \times 10 \mathrm{~mL}$ portions of $\mathrm{ACN}$. The extracts were evaporated on a water bath $(70$ $90^{\circ} \mathrm{C}$ ). The last traces of solvent were removed using a current of dry air. The Maneb content in the residue was determined by the general procedure and the results indicated good recoveries in all cases. The results of the determinations were given in Table 3.

\subsubsection{Sample Preparation for Soft Drinks}

The soft drinks (coke and limca) were locally obtained. These were diluted ten times, filtered and spiked with known amount of maneb solution. The maneb content was determined by the general procedure using a reagent blank prepared under similar conditions.

\subsection{Determination of Maneb in Commercial Samples}

The method was applied for determination of Maneb in a commercial samples and. The formulated product sample solutions were prepared as discussed earlier and determined by the general procedure. The results of the determinations were given in Table 4.

\subsection{Simultaneous Determination of Maneb in Presence of Ziram in Synthetic Mixtures}

The method was applied for the simultaneous determination of Ziram and Maneb in synthetic mixtures. Ziram forms a yellow complex with sodium molybdate in cold, which absorbs at $420 \mathrm{~nm}$ (21) whereas Maneb forms complex on heating, all other conditions remaining the same. Synthetic mixtures of maneb and ziram were made in different proportions. To the binary mixture, $0.15 \mathrm{~mL}$ of $2 \mathrm{~mol} \cdot \mathrm{L}^{-1}$ of $\mathrm{H}_{2} \mathrm{SO}_{4}$ and $2 \mathrm{~mL}$ of $2 \%$ sodium molybdate were added. Molybdenum-ziram complex was extracted

Table 3. Determination of Maneb in fortified samples (mean values and standard deviations, $\mathbf{n}=\mathbf{5}$ ).

\begin{tabular}{|c|c|c|c|c|}
\hline Fungicide & Sample & Maneb added $(\mu \mathrm{g})$ & Maneb found $(\mu \mathrm{g})$ & Recovery $(\%) \pm$ RSD $(\%)$ \\
\hline \multirow{11}{*}{ Maneb } & \multirow{3}{*}{ Wheat } & 10 & 9.8 & $98 \pm 2.1$ \\
\hline & & 15 & 14.9 & $99.3 \pm 1.9$ \\
\hline & & 20 & 19.8 & $99 \pm 1.9$ \\
\hline & \multirow{2}{*}{ Cabbage } & 8 & 7.8 & $97.5 \pm 2.2$ \\
\hline & & 10 & 9.7 & $97 \pm 1.9$ \\
\hline & \multirow{3}{*}{ Coke } & 10 & 9.1 & $91 \pm 2.4$ \\
\hline & & 20 & 18.6 & $93 \pm 2.1$ \\
\hline & & 25 & 23.9 & $95.6 \pm 2.5$ \\
\hline & \multirow{3}{*}{ Limca } & 10 & 9.0 & $90 \pm 2.2$ \\
\hline & & 20 & 18.2 & $91 \pm 1.8$ \\
\hline & & 25 & 23.6 & $94.4 \pm 1.8$ \\
\hline
\end{tabular}


Table 4. Determination of Maneb in commercial samples (mean values and standard deviations, $\mathbf{n}=\mathbf{5}$ ).

\begin{tabular}{|c|c|c|c|c|c|}
\hline \multirow{2}{*}{$\begin{array}{l}\text { Commercial } \\
\text { Sample }\end{array}$} & \multirow{2}{*}{$\begin{array}{l}\text { Maneb taken } \\
\qquad(\mu \mathrm{g})\end{array}$} & \multirow{2}{*}{$\begin{array}{l}\text { Maneb found } \\
(\mu \mathrm{g})\end{array}$} & \multirow{2}{*}{ Recovery $(\%) \pm \operatorname{RSD}(\%)$} & \multicolumn{2}{|c|}{ Rangaswamy et al. method ${ }^{22}$} \\
\hline & & & & Maneb found $(\mu \mathrm{g})$ & Recovery \% \\
\hline \multirow{3}{*}{$\begin{array}{c}\text { Dithiane } \\
\text { M-45 (80\% W.P.) }\end{array}$} & 20 & 19.9 & $99.5 \pm 1.5$ & 19.7 & 98.5 \\
\hline & 30 & 30 & $100 \pm 1.8$ & 29.8 & 99.3 \\
\hline & 40 & 39.9 & $99.8 \pm 1.6$ & 39.8 & 99.5 \\
\hline \multirow{3}{*}{$\begin{array}{c}\text { Dithiane } \\
\text { M-22 (80\% W.P.) }\end{array}$} & 20 & 19.8 & $99 \pm 1.6$ & 19.7 & 98.5 \\
\hline & 30 & 29.8 & $99.3 \pm 1.4$ & 29.6 & 98.7 \\
\hline & 40 & 39.9 & $99.8 \pm 1.5$ & 39.8 & 99.5 \\
\hline
\end{tabular}

Table 5. Determination of Maneb and Ziram in synthetic mixtures (mean values and standard deviations, $\mathbf{n}=\mathbf{5}$ ).

\begin{tabular}{cccccc}
\hline \multirow{2}{*}{$\begin{array}{c}\text { Maneb added } \\
(\mu \mathrm{g})\end{array}$} & $\begin{array}{c}\text { Ziram added } \\
(\mu \mathrm{g})\end{array}$ & $\begin{array}{c}\text { Maneb found } \\
(\mu \mathrm{g})\end{array}$ & $\begin{array}{c}\text { Ziram found } \\
(\mu \mathrm{g})\end{array}$ & \multicolumn{2}{c}{ Recovery $(\%) \pm$ RSD $(\%)$} \\
\cline { 5 - 6 } & & 29.5 & 38.8 & Maneb & Ziram \\
\hline 30 & 40 & 19.6 & 29.0 & $98.3 \pm 2.3$ & $97 \pm 2.3$ \\
15 & 30 & 14.5 & 19.0 & $96.7 \pm 2.1$ & $96.7 \pm 2.5$ \\
\hline
\end{tabular}

Table 6. Comparison of molar absorptivities of Maneb complexes.

\begin{tabular}{|c|c|c|c|}
\hline Procedure & $\begin{array}{l}\text { Molar Absorptivity } \\
\quad\left(\mathrm{L} \cdot \mathrm{mol}^{-1} \cdot \mathrm{cm}^{-1}\right)\end{array}$ & Remarks & Reference \\
\hline Molybdenum & $0.4 \times 10^{4}$ & Low sensitivity and selectivity & 23 \\
\hline Rangaswamy et al. method & - & $\begin{array}{l}\text { Low sensitivity, long tedious } \\
\text { procedure }\end{array}$ & 24 \\
\hline $\begin{array}{l}\text { Complex formation with diphenylcarbazone } \\
\text { and pyridine }\end{array}$ & $6.5 \times 10^{4}$ & $\begin{array}{l}\text { Extraction not rapid and uses } \\
\text { toxic pyridine }\end{array}$ & 25 \\
\hline Complex formation with PAN & $4.1 \times 10^{4}$ & $\begin{array}{l}\text { Less sensitive than present me- } \\
\text { thod }\end{array}$ & 26 \\
\hline $\begin{array}{l}\text { Molybdenum (at } 956 \mathrm{~nm} \text { ) and derivative } \\
\text { spectrophotometry }\end{array}$ & $8.1 \times 10^{4}$ & Better sensitivity & Present work \\
\hline
\end{tabular}

into $5 \mathrm{~mL}$ MIBK and maneb remained in aqueous phase. The absorbance of ziram-molybdenum complex was measured at $420 \mathrm{~nm}$. To the aqueous phase containing maneb was added $1 \mathrm{~mL} 4 \mathrm{~mol} \cdot \mathrm{L}^{-1} \mathrm{H}_{2} \mathrm{SO}_{4}$ and $2 \mathrm{~mL}$ of $2 \%$ $\mathrm{Na}_{2} \mathrm{MoO}_{4}$ solution. The solution was boiled for 5 minutes, cooled and extracted into $5 \mathrm{~mL}$ MIBK, the spectra of blue complex of maneb was taken between $600 \mathrm{~nm}$ and $1100 \mathrm{~nm}$. Thus, this method was applied for the simultaneous determination of ziram and maneb. Ziram was determined from the standard calibration curve. The results of the determinations are given in Table 5 .

\section{Conclusions}

The present method is more sensitive than the carbon disulphide evolution methods. It is superior to the reported methods and the direct simultaneous determination of ziram and maneb is possible. The sensitivity of the present method is comparable to other spectrophotometric methods (Table 6). The selectivity of the present method is superior to other methods. The wide applicability of this method makes it suitable for dithiocarbamate analysis in foodstuffs and in commercial samples.

\section{References}

[1] FAO Specifications for Plant Protection Products, "Maneb (Manganese Ethylenebisdithiocarbamate)," Food and Agriculture Organisation of the United Nations, Rome, 1979.

[2] "Risks of Mancozeb and Maneb Uses to the Federally Listed California Red Legged Frog (Rana Aurora Draytonii)," Pesticide Effects Determination, Office of Pesticide Programs, Washington DC, 2007.

[3] J. W. Hylin, "Oxidative Decomposition of Ethylenebis-Dithiocarbamates," Bulletin of Environmental Con- 
tamination and Toxicology, Vol. 10, No. 4, 1973, pp. 227-233. doi:10.1007/BF01684549

[4] W. D. Marshall and W. R. Jarvis, "Procedures for the Removal of Field Residues of Ethylenebis (Dithiocarbamate) (EBDC) Fungicides and Ethylenethiourea (ETU) from Tomatoes Prior to Processing into Juice," Journal of Agricultural and Food Chemistry, Vol. 27, No. 4, 1979, pp. 766-769. doi:10.1021/jf60224a045

[5] K. L. Dearfield, "Ethylene Thoiurea (ETU): A Review of Genetic Toxicity Studies," Mutation Research, Vol. 317, No. 2, 1994, pp. 111-132.

[6] B. M. Ulland, J. H. Weisburger, E. K. Weisburger, J. M. Rice and R. Cypher, "Thyroid Cancer in Rats from Ethylene Thiourea Intake," Journal of National Cancer Institute, Vol. 49, No. 2, 1972, pp. 583-584.

[7] Ministry of Agriculture Fisheries and Food, "Committee for Analytical Methods for Residue of Pesticides and Veterinary Products in Food Stuffs," Analyst, Vol. 106, No. 1264, 1981, pp. 782-787. doi:10.1039/an9810600782

[8] H. S. Rathore, G. Varshney and K. Ishratullah, "Assessment of the Movement of Some Dithiocarbamate Fungicides by Soil Thin Layer Chromatography," Indian Journal of Chemical Technology, Vol. 14, No. 4, 2007, pp. 400-406.

[9] R. Kesari and V. K. Gupta, "A Sensitive Spectrophotometric Method for the Determination of Dithiocarbamate Fungicide and Its Application in Environmental Samples," Talanta, Vol. 45, No. 6, 1998, pp. 1097-1102. doi:10.1016/S0039-9140(97)00208-7

[10] J. W. Hylin, Y. Kawano and W. Chang, "An Ultraviolet Absorption Method for the Analysis of Maneb Formulations," Bulletin of Environmental Contamination and Toxicology, Vol. 20, No. 1, 1978, pp. 840-845. doi:10.1007/BF01683609

[11] A. R. Türker and B. Sezer, "Indirect Determination of Dithiocarbamate Fungicides (zineb and ferbam) in Some Foodstuffs by Flame Absorption Spectrometry," Turkish Journal of Pharmaceutical Sciences, Vol. 2, No. 1, 2005, pp. $35-42$.

[12] G. Crnogorac and W. Schwack, "Residue Analysis of Dithiocarbamate Fungicides," Trends in Analytical Chemistry, Vol. 28, No. 1, 2009, pp. 40-50. doi:10.1016/j.trac.2008.10.008

[13] A. Waseem, M. Yaqoob and A. Nabi, "Photodegradation and Flow-Injection Determination of Dithiocarbamate Fungicides in Natural Waters with Chemiluminescence Detection," Analytical Sciences, Vol. 25, No. 3, 2009, pp. 395-400. doi:10.2116/analsci.25.395

[14] Z. Vryzas, E. N. Papadakis and E. Papadopoulou-Mourkidou, "Microwave-Assisted Extraction (MAE)-Acid Hydrolysis of Dithiocarbamates for Trace Analysis in Tobacco and Peaches," Journal of Agricultural and Food Chemistry, Vol. 50, No. 8, 2002, pp. 2220-2226. doi:10.1021/jf0111864

[15] C. C. Lo, M. H. Ho and M. D. Hung, "Use of High Performance Liquid Chromatographic and Atomic Absorp- tion Methods to Distinguish Propineb, Zineb, Maneb and Mancozeb Fungicides," Journal of Agricultural and Food Chemistry, Vol. 44, No. 9, 1996, pp. 2720-2723. doi:10.1021/jf9600081

[16] W. Shwack, B. Brüger and S. Nyanzi, "Simultaneous Differential Pulse Polarographic Determination of $\mathrm{CS}_{2}$ and COS Gases and Its Application in the Analysis of Dithiocarbamate Fungicide Residues in Foods," Fresenius Journal of Analytical Chemistry, Vol. 351, No. 2-3, 1995, pp. 297-300. doi:10.1007/BF00321651

[17] H. B. Česnik and A. Gregorčič, "Validation of the Method for the Determination of Dithiocarbamate and Thiuram Disulphide in Apple, Lettuce, Potato, Strawberry and Tomato Matrix," Acta Chimica Slovenia, Vol. 53, No. 1, 2006, pp. 100-104.

[18] G. Crnogorac, S. Schmauder and W. Schwack, "Trace Analysis of Dithiocarbamate Fungicide Residues on Fruits and Vegetables by Hydrophilic Interaction Liquid Chromatography/Tandem Mass Spectrometry," Rapid Communications in Mass Spectrometry, Vol. 22, No. 16 2008, pp. 2539-2546. doi:10.1002/rcm.3646

[19] A. F. Grand and M. Tamres, "Titration of Some Metal Diethyldithiocarbamates by Iodine in Chloroform," Analytical Chemistry, Vol. 40, No. 12, 1968, pp. 1904-1905. doi:10.1021/ac60268a041

[20] D. D. Clyde, "Determination of Xanthates, DithiocarBamates and Some Fungicides by Titration with Electrogenerated Iodine in Anhydrous Acetonitrile," Journal of Associaton of Official Analytical Chemists, Vol. 66, No. 3, 1983, pp. 646-650.

[21] A. S. Hyman, "A Rapid Method for the Determination of Manganese in Maneb and Its Formulations," Analyst, Vol. 94, No. 1115,1969 , pp. 152-153. doi:10.1039/an9699400152

[22] A. K. Malik and A. L. J. Rao, "Spectrophotometric Determination of Zineb (a Dithiocarbamate Fungicide) by Methylene Blue Method," Talanta, Vol. 37, No. 12, 1990, pp. 1205-1207. doi:10.1016/0039-9140(90)80194-K

[23] N. Verma, "Spectrophotometric and Polarographic Estimation of Some Pesticides and Metallic Poisons," Ph.D. Dissertation, Punjabi University, Patiala, 1985.

[24] J. R. Rangaswamy and Y. N. Vijayashankar, "A Rapid Method for the Determination of Manganese Ethylenebisdithiocarbamate and Its Residues on Grains," Journal of Association of Official Analytical Chemists, Vol. 58, No. 6, 1975, pp. 1232-1234.

[25] A. K. Malik, J. Kapoor and A. L. J. Rao, "Spectrophotometric Determination of Manganese Ethylenebis Dithiocarbamate (MANEB) with Diphenylcarbazone," Research Journal of Chemistry and Environment, Vol. 1, No. 1, 1992, pp. 29-33.

[26] A. L. J. Rao, A. K. Malik and J. Kapoor, "Extraction Spectrophotometric Determination of Maneb with 1-(2'pyridylazo)-2-naphthol (PAN)," Talanta, Vol. 40, No. 2, 1993, pp. 201-203. doi:10.1016/0039-9140(93)80322-I 